\title{
DEFINING PERSONNEL MARKETING STRATEGIES
}

\author{
Olena GLADKA ${ }^{1}$, Victoria FEDOROVA ${ }^{2}$
}

\author{
${ }^{1}$ Independent researcher \\ ${ }^{2}$ Department of Economics and Entrepreneurship, Faculty of Management and Business, \\ Kharkiv National Automobile and Highway University, \\ Ukraine, 61002, Kharkiv, 25 Yaroslava Mudrogo St. \\ E-mails: ${ }^{1}$ olena.gladka@gmail.com (corresponding author); ${ }^{2}$ pobedaviktory5@gmail.com
}

Received 10 November 2018; accepted 01 March 2019

\begin{abstract}
The purpose of the study is to develop methodological basis as to the justification and selection of personnel marketing strategy based on logical analysis and systematic approach. The strategy is suggested to be developed taking into consideration external personnel marketing strategy and internal one. The former is based on the capacity of an employer to meet expectations of potential personnel and is aimed at forming enterprise's external attractiveness as an employer. The latter is based on the capacity of an employer to satisfy expectations of existing personnel and is aimed at forming enterprise's internal attractiveness as an employer. The choice of strategy is based on the Matrix determining the generalized level of enterprise's attractiveness as an employer. This Matrix allows identifying nine types of personnel marketing strategies. The content of each type of personnel marketing strategy was substantiated. The main actions contributing to the improvement of level of enterprise's attractiveness as an employer internally and externally were developed based on the 7Ps personnel marketing mix. Results of this study have theoretical and practical significance. They can be used as basis for further studies, while developed recommendations can be used by a management team for implementation within an enterprise that seeks to develop its employer attractiveness.
\end{abstract}

Keywords: personnel marketing strategy, personnel marketing, employer's attractiveness, personnel marketing strategy matrix, 7Ps personnel marketing mix.

JEL Classification: L21, M1, M31, Z22.

\section{Introduction}

Nowadays success of any enterprise on the market largely depends on the level of professionalism, as well as on the technical and soft skills of its employees. According to a study led by International recruitment company Hays (www. hays-index.com) together with the Oxford Economics Institute of Forecasting (https://www.oxfordeconomics. com) in 2017, Europe is experiencing a growing mismatch between business needs and employees' competencies. For example, in Poland, this mismatch indicator increased from 3.3 to 6.1 between 2013 and 2017, and in the Czech Republic - from 0.7 to 5.3 (the indicator is measured on a scale from 0 to 10 , where the minimum value " 0 " means there is no mismatch). This aspect highlights the problem of increasing competition for talents between companies on labour markets.

Due to the phenomenon of globalisation, special attention requires problem of the qualified workforce shortage on national markets. In such context national companies lose the "war for talents" to their global competitors. Partially that might be due to the fact that global companies are usually entering the national markets with already established enterprise's attractiveness as an employer. That is to say, on local labour markets those companies with "global origins" struggle less for attracting and retaining best talents than their competitors with "national origins".

Clear evidences of that are shown in several studies. For example, each year the Top Employers Institute (https://

\footnotetext{
Copyright $\odot 2019$ The Authors. Published by VGTU Press.

This is an Open Access article distributed under the terms of the Creative Commons Attribution License (http://creativecommons.org/licenses/by/4.0/), which permits unrestricted use, distribution, and reproduction in any medium, provided the original author and source are credited..
} 
www.top-employers.com/) conducts assessment on national, regional and global levels to identify top employers. The latest years showed that in Eastern European countries, top employer nominations win globally originated companies (in Poland, Ukraine, Lithuania or Belarus these companies are: PepsiCo, Accenture, JTI, PMI, BNP Barisbas, in Czech Republic - Brose, Avon, DHL, Dimension Data, Faurecia). Another research is being conducted by Universum Company (https://universumglobal.com/) among graduates to identify their employment preferences on the national, regional and global levels. Data analysis shows that the leading positions are still kept by global companies (in Poland, Romania or Bulgaria they are Audi, Google, Apple, Microsoft, L'Oréal, in Czech Republic they are Skoda, Siemens, Bosch, Honeywell, Google). This list can be extended by examples of many other researches, containing the same evidences.

In such toughened conditions national enterprises have to look closer on the problem as to the long-term employees' retention and their attraction on the labour markets. Each company have to make sure its attractiveness as an employer is strong enough internally and externally. First of all it will allow retaining top talents that have a required set of skills. Secondly it will play a vital role to significantly reduce the cost on attracting new employees and simultaneously the staff turnover.

One of the possible ways to solve this problem is the implementation of personnel marketing within enterprises. In previous research results it was substantiated that, personnel marketing is a managerial activity of an enterprise aimed at simultaneously meeting its needs in necessary personnel and the identified needs of existing and potential employees by retaining (or attracting) them through a set of measures ensuring attractiveness of positions / vacancies, payments / remuneration, etc.

The main purpose of personnel marketing activity is the development of enterprise's attractiveness as an employer. To create and maintain the latter on a certain level on labour markets, it is crucial to have a strategy. This strategy should take into account the expectations and needs of both potential and existing employees, that is, to have an integrated approach.

The importance of applying this approach while developing a personnel marketing strategy is explained by the fact that the level of enterprise's attractiveness as an employer is assessed not only by the existing personnel, but also by former employees and new applicants / candidates.

Thus, the main purpose of this study is to develop methodological basis as to the personnel marketing strategies' justification and selection by applying logical analysis and systematic approach. In accordance to this purpose the following tasks should be solved: first one is to identify stages of the process of personnel marketing strategy development, second one is to define the main types of the strategies.

\section{Literature overview}

The literature overview has shown that there are no approaches as to the development of personnel marketing strategy aiming to the employees' attraction and long-term retention, as well as to the formation of employer's attractiveness.

When studying the problem of employees' attraction and retention, most often authors refer to the two following concepts:

1) the concept of "employer branding"; and

2) the concept of "employee experience".

The essence of the first concept - the one of employer brand, was first substantiated by scientists Tim Ambler and Simon Barrow (1996), as "the package of functional, economic and psychological benefits provided by employment, and identified with the employing company. The main role of the employer brand is to provide a coherent framework for management to simplify and focus priorities, increase productivity and to improve recruitment, retention and commitment". Since then the employer branding concept has evolved. Results of Ambler's and Simon's work found their development in other academic researches. Most often the employer brand is being studied as a tool for talents' attraction and retention (Wilden et al. 2010, Gilani and Cunningham 2017, Botha et al. 2011, Potgieter and Doubell 2018, Collins and Stevens 2002). While other researches are dedicated to study attributes (Lievens and Highhouse 2003, Maxwell and Knox 2009, Sutherland et al. 2002) or characteristics (Moroko and Uncles 2008) that contribute to the development of employer's attractiveness. A survey Conducted by Randstad group (https://www.randstad. $\mathrm{com} /$ ) on yearly basis aimed to analyze employer's attractiveness attributes globally and regionally with a breakdown of target groups to age, gender or sector of employment.

As to the formation of employer branding strategy there are two main approaches:

a) according to the first one, the employer's brand concept strategic incorporation into the HR function due to the fact that it covers simultaneously several HR areas (Chhabra and Mishra 2008, Robertson and Khatibi 2013, Backhaus and Tikoo 2004, Mandhanya and Shah 2010). For example, Robertson and Khatibi (2013) relates this need to enhance employees' productivity, stating that "well-developed employer branding strategy enables an organization to achieve significantly higher employee productivity related outcomes than with a partially-developed or undeveloped strategy". While Backhaus and Tikoo (2004) think that integrating employer branding into HR activities (recruitment, staffing, training and development and career management) enables possibility to build coordinated HR strategies. According to Mandhanya and Shah (2010), incorporating employer branding into the talent management is "the 
essence of the employment experience, providing points that commence with initial employer brand awareness and continuing through the tenure of employment, even extending into retirement";

b) according to the second one, the employer brand must have its own separate strategy. For instance, Brett Minchington (2011), a well-known strategist from International Employer Brand, states that: "a contemporary approach to employer branding requires a strategic perspective towards how the company attracts, engages and retains talent". He refers to the importance of building up employer brand strategy around employee lifecycle within one organization, that is, to build for each employee a unique employment experience (defined as "the pathway a person takes from exploring an employer to work for to their retirement or rehire and the experiences encountered at each "touchpoint").

As to the second concept - the one of employee experience, it has been developed within the last decade. The purpose of its activities is nearly close to the one of personnel marketing and they are aiming at creating an employee long-term engagement and retention (Seiko 2018, Hulce 2018, Harter 2018, Ellis 2018, Del Rowe 2018, Arnold 2018). Employee experience can be identified as an employee's perception, feelings and observation regarding their employers that they get throughout the employment lifecycle.

Jacob Morgan (a well-known author, speaker and futurist, who explores how the workplace is changing) enhances the notion by giving his own definition: "an employee experience is the combination of three distinct things that exist within any organization regardless of industry, size, and location; they are organization's cultural, physical, and technological environments." (Morgan 2016, 2018).

It is thought that a positive employee experience is contributing to attracting and retaining top talents and to winning the today's war for talents. Additionally, according to the recent studies of the consulting company Deloitte (https://www2.deloitte.com) there is statistical relationship between increases in frontline engagement, increases in customer service, and revenue growth. In order to build-up an exceptional employee experience Deloitte developed an approach dedicated "to reimagine and craft the employee experience, to help generate higher engagement, satisfaction, and strategic alignment to drive brand differentiation, customer service excellence, and growth". Deloitte consultants (Bersin et al. 2017) in their research state that "through new approaches such as design thinking and employee journey maps, HR departments are now focusing on understanding and improving this complete experience and using tools such as employee net promoter scores to measure employee satisfaction".

In the context of the employee experience concept the employee experience strategy is built around an employee's lifecycle by creating a unique experience starting from the moment when a potential employee finds a job posting from an employer and decides to apply to it till the moment of his/her leaving and/or retirement.

To sum up the above, the analysis of literature sources has shown that the researchers consider only particular aspects of the personnel marketing strategy development; and the identified approaches are not covering tasks in their interrelated complex, only separate problems are being solved. Thus, in the framework of this study, we believe that:

1) employer branding concept has a narrower meaning than personnel marketing has. Therefore the development of an employer branding strategy only somewhat narrows down the scope of an enterprise's activity dedicated to ensure itself with the necessary personnel, through the employees' attraction and long-term retention, through the formation of employer's attractiveness; whilst

2) employer experience concept has a broader meaning than employer branding. The development of the employee experience around employee lifecycle makes the process more complex, covering larger scope of activities including as well the ones related to employer attractiveness development. The employee experience is built in complex for all employment lifecycle processes (employee's joining, growing, rewarding, contribution etc). However concentrating only on separate processes and on the internal environment, the concept itself can exclude possibility to influence external environment related factors (e.g. there is no clear correlation between recruitment and the growth processes; they do not complement each other).

In previous research results it was justified that employer branding is one of the components of 7Ps marketing mix of the personnel marketing concept. And it is aimed at promoting an enterprise as an employer (by spreading out information regarding the benefits that employer has to offer to its employees, by promoting benefits that may have "value" for a selected target audience, that is the employer value proposition). Besides employer's external and internal branding, personnel marketing also includes other components such as position and package of services according to the position, compensation package, external and internal communication, all categories of current employees contacting with candidates, workflow of the external (internal) personnel marketing, physical environment. Thus employer branding contributes to the activity related to the attraction of potential and retention of existing employees. While the enterprise's attractiveness as an employer is built within the framework of the personnel marketing process. Hence, the personnel marketing strategy is designed to develop or reshape the attractiveness of the enterprise as an employer. The personnel marketing strategy takes into consideration 
measured internal and external 7Ps indicators and identify the best and realistic way of the organizational development, aiming at long-term improvements.

The suggested approach of the personnel marketing strategy development is based on the personnel marketing concept (from the perspective of enterprise), the ground basis for which served the concept of classic marketing (Kotler 1997). In the framework of this concept, the company seeks to identify needs of employees (potential and existing) and to meet the identified needs of selected employees accordingly by providing them with the necessary positions containing appropriate quantitative and qualitative characteristics, and thereby satisfying its own need in the necessary personnel. That is to say that employer seeks to be attractive for the target audiences of employees in order to attract or retain them. In this study employer attractiveness is defined as subjective evaluation of specific target audience given to an employer value proposition (EVP) on the labor market and to its (EVP's) ability to meet needs of this audience internally within an enterprise. While employer value proposition is defined as a set of qualities and characteristics of the employer, which serve as basis to create the attractiveness of the enterprise as an employer in order to attract or retain target audiences on the external labor market or internally accordingly.

The strategy of personnel marketing should imply a model of enterprise's actions that on the one hand aimed at formation of the EVP on the labor market. On the other hand, they are directed to ensure EVP's compliance with the expectations and needs of the target audience.

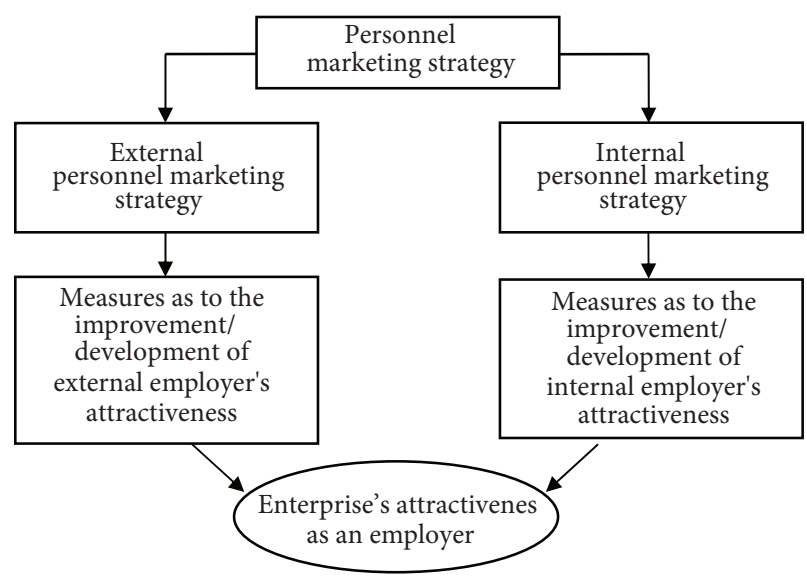

Figure 1. Hierarchy of personnel marketing strategy

\section{Results of the study}

Taking into consideration all the above mentioned, personnel marketing strategy is proposed to develop in two directions:

- development of personnel marketing strategy, that considers potential employees and forms employer's external attractiveness;

- development of personnel marketing strategy, that considers existing employees and forms employer's internal attractiveness.

Hence, the main thesis is that the personnel marketing strategy should combine interests of both potential and existing employees. Thus, this should define the directions

\begin{tabular}{|l|c|}
\hline 1 & Identifying the target audience, for which the personnel marketing should be developed \\
\hline 2 & Evaluation of external \\
\hline & Defining the generalized level of enterprise's attractiveness as an employer \\
based on the Matrix
\end{tabular}

Figure 2. Stages of stages personnel marketing strategy development 
as to the improvement of generalized level of employer's attractiveness (Figure 1).

Methodology of personnel marketing strategy development represents consistent set of coordinated procedures related to research, analysis and calculation (represented below, Figure 2).

Stage 1. Identifying the target audience, for which the personnel marketing should be developed.

The content of personnel marketing activities depends on the target audience for which the activity is being led. Target audience can be represented by both existing and potential employees of the enterprise.

Through the implementation of internal personnel marketing the company ensures itself with the necessary employees by retaining them. While external personnel marketing ensures the company with the necessary employees by attracting them on the external labour market. These two types of personnel marketing are closely interrelated.

The company implements measures to retain existing personnel, which are subsequently transmitted through a communication system on the external labour market to potential employees as "promises". At the same time, measures are being taken to attract potential employees, who expect the company to fulfil "given promises" after they join the company.

Stage 2. Evaluation of external enterprise's attractiveness as an employer.

This evaluation is proposed to conduct based on the multicriteria and fuzzy logic based methodology. This methodology ensures the integrated assessment of the employer attractiveness through indicators that reflect different requirements of potential employees towards their future employers (Gladka 2013).
Stage 3. Evaluation of internal enterprise's attractiveness as an employer.

It is suggested to use approach which is based on the point rating method. It allows determining the employer's internal attractiveness through indicators that reflect the level of satisfaction of employees' expectations (Kryvoruchko and Gladka 2014).

Both external and internal employer's attractiveness use indicators, developed in previous research results based on 7Ps personnel marketing mix.

Stage 4. Defining the generalized level of enterprise's attractiveness as an employer based on the Matrix.

The nine-box Matrix is a tool that is built in a twodimensional plane formed by indicators of external and internal employer's attractiveness (Figure 3).

The arrows on the figure indicate possible directions for development of the employer attractiveness.

On the horizontal line of the Matrix the level of indicators for employer's external attractiveness is marked, while on the vertical line - the level of employer's internal attractiveness.

The indicators that are used in the two mentioned above approaches for the evaluation of employer's internal or external attractiveness can vary in the intervals between 0 and 1. When assed, the attractiveness can be placed in one of the three ranges according to the evaluation results:

a) for low level of attractiveness: range is between 0 and 0.33 ;

b) for medium level of attractiveness: range is between 0.34 and 0.67 ;

c) for high level of attractiveness: range is between 0.68 and 1 .

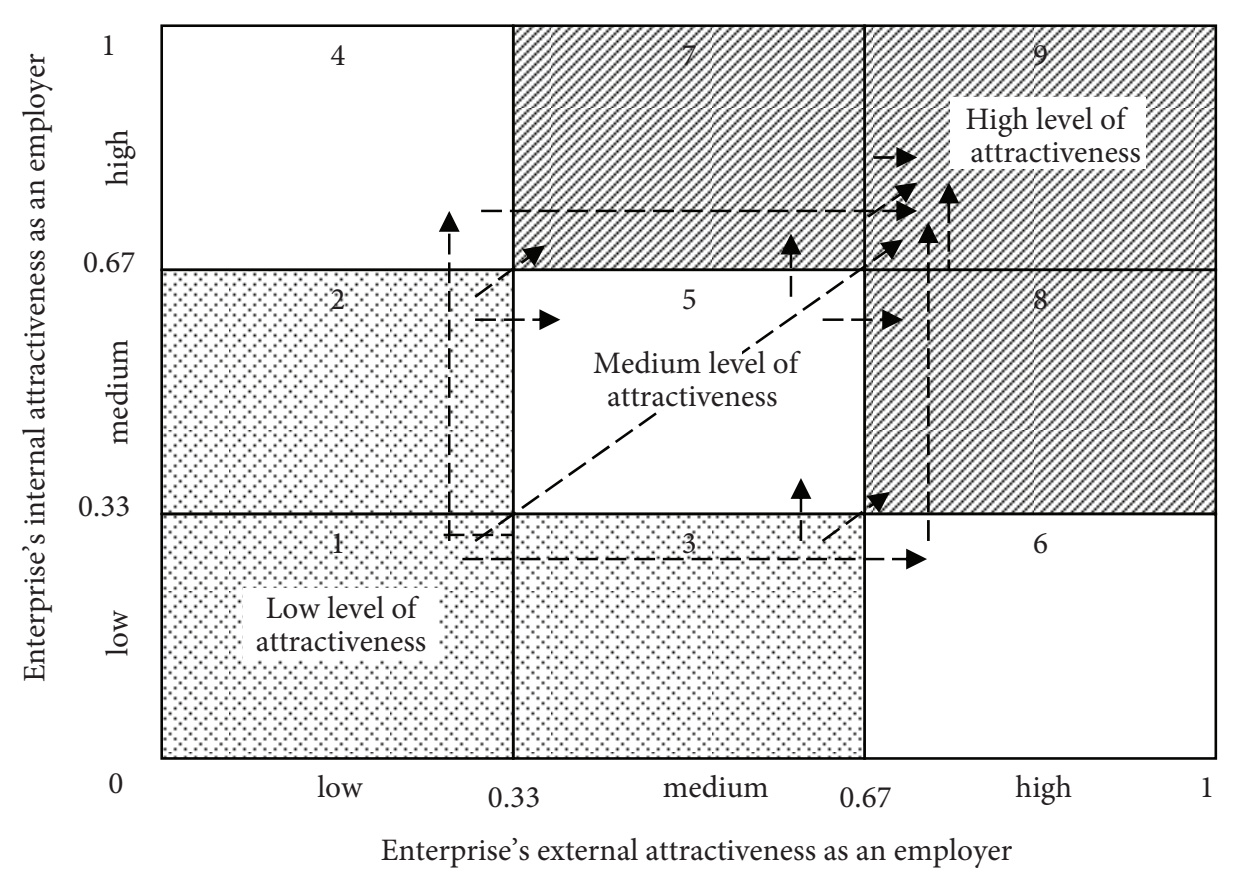

Figure 3. Matrix of generalized level of enterprise's attractiveness as an employer 
The Matrix is divided into nine cells. Each cell represents a combination of evaluation results for employer's external and internal attractiveness. Each cell has its own zone: cells 1 to 3 - light grey colored - represent zone of low level of attractiveness; cells 4 to 6 - no colored - represent zone of medium level of attractiveness, cells 7 to 9 - dark gray colored - represent zone of high level of attractiveness.

When combining evaluation results of both external and internal employer's attractiveness the enterprise can fit in one of the nine boxes (cells), described below in Table 1 .

\section{Stage 5. Defining personnel marketing strategy.}

According to the generalized level of enterprise's attractiveness as an employer, the choice of a personnel marketing strategy is made based on the Matrix. Typical strategies of personnel marketing development are shown below, on the Figure 4.
If the generalized level of employer attractiveness corresponds to cells $1-3$ it is suggested to follow one of three strategies that aimed at creating and/or "renewing" the attractiveness, since the attractiveness itself should either be created from scratch or fundamentally revamped internally and/or externally.

In case when the attractiveness corresponds to the cells 4-6 and defined as medium, it is recommended to follow one of the three strategies of the employer's attractiveness improvement and/or "correction", since they imply a set of actions addressed to increase its level either externally or internally, or equally in both directions.

The last segment represented by cells 7-9 and corresponds to the high level of generalized employer attractiveness. Meaning for enterprise to follow strategies of the attractiveness' maintenance and/or monitoring.

Table 1. Characteristics of the Matrix cells determining the generalized level of enterprise's attractiveness as an employer

\begin{tabular}{|c|c|c|c|c|}
\hline \multirow{2}{*}{ No. } & \multicolumn{2}{|c|}{ Attractiveness level ranges } & \multirow{2}{*}{$\begin{array}{l}\text { Generalized } \\
\text { level of attrac- } \\
\text { tiveness }\end{array}$} & \multirow{2}{*}{ Characteristics of the cells of the Matrix } \\
\hline & external & internal & & \\
\hline 1 & $0-0.33$ & $0-0.33$ & low & $\begin{array}{l}\text { an enterprise has a low level of both external and internal attractiveness as an } \\
\text { employer. The attractiveness is either not developed yet or it requires fundamen- } \\
\text { tal changes by introducing/developing new personnel marketing measures }\end{array}$ \\
\hline 2 & $0-0.33$ & $0.33-0.67$ & low & $\begin{array}{l}\text { an enterprise has a low level of external attractiveness and a medium level of } \\
\text { internal attractiveness as an employer. In this case managerial activities should } \\
\text { be aimed at introducing/developing new measures for external personnel mar- } \\
\text { keting and at improving/upgrading the existing measures for internal personnel } \\
\text { marketing }\end{array}$ \\
\hline 3 & $0.33-0.67$ & $0-0.33$ & low & $\begin{array}{l}\text { an enterprise has a medium level of external and a low level of internal attracti- } \\
\text { veness as an employer. The company should introduce/develop new internal } \\
\text { personnel marketing measures and improve/upgrade existing ones for external } \\
\text { personnel marketing. }\end{array}$ \\
\hline 4 & $0-0.33$ & $0.67-1$ & medium & $\begin{array}{l}\text { an enterprise has a low level of external and high level of internal attractiveness } \\
\text { as an employer. To increase the external attractiveness, it is necessary to introdu- } \\
\text { ce/develop new measures for external marketing. While, internal attractiveness } \\
\text { requires constant monitoring of its changes' dynamics. }\end{array}$ \\
\hline 5 & $0.33-0.67$ & $0.33-0.67$ & medium & $\begin{array}{l}\text { an enterprise has an average level of both external and internal attractiveness as } \\
\text { an employer. There is always a room for improvement of attractiveness level as } \\
\text { long as the enterprise constantly improves measures for external and internal } \\
\text { personnel marketing. }\end{array}$ \\
\hline 6 & $0.67-1$ & $0-0.33$ & medium & $\begin{array}{l}\text { an enterprise has a high level of external and a low level of internal attractiveness } \\
\text { as an employer. On one hand, in order to increase the internal attractiveness, it } \\
\text { is necessary to introduce new measures for internal personnel marketing. On } \\
\text { the other hand, in order to maintain external attractiveness on a certain level, it } \\
\text { is necessary to constantly monitor dynamics of its changes. }\end{array}$ \\
\hline 7 & $0.33-0.67$ & $0.67-1$ & high & $\begin{array}{l}\text { an enterprise has an average level of external and a high level of internal } \\
\text { attractiveness as an employer. In order to improve the external attractiveness } \\
\text { of the employer, it is necessary to improve the measures of external personnel } \\
\text { marketing accordingly. }\end{array}$ \\
\hline 8 & $0.67-1$ & $0.33-0.67$ & high & $\begin{array}{l}\text { an enterprise has a high level of external and medium level of internal attracti- } \\
\text { veness as an employer. In order to improve the attractiveness internally, it is } \\
\text { necessary to improve the measures of internal personnel marketing accordingly. }\end{array}$ \\
\hline 9 & $0.67-1$ & $0.67-1$ & high & $\begin{array}{l}\text { an enterprise has a high level of external and internal attractiveness as an em- } \\
\text { ployer. The main task of the enterprise is to constantly monitor changes of the } \\
\text { attractiveness level and to maintain it at the achieved level. }\end{array}$ \\
\hline
\end{tabular}




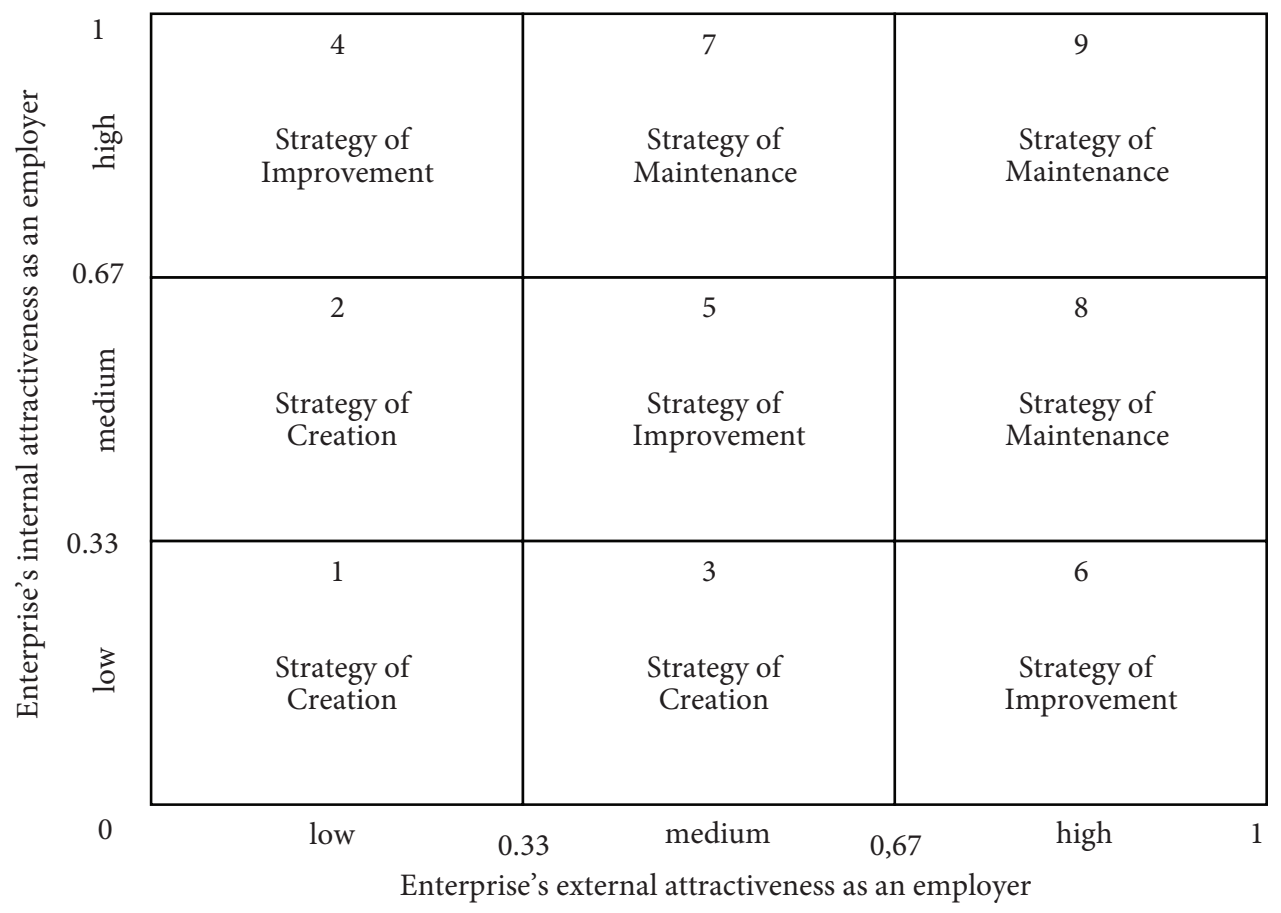

Figure 4. Matrix defining the personnel marketing strategy

\section{Research results and discussion}

This section presents the results of the study by applying the developed methodology as to the defining personnel marketing strategy. Table 2 presents the interpretation of results obtained after the selection of the strategy.
Thus, depending on which cell of the Matrix the enterprise belongs to, the personnel marketing strategies are recommended accordingly (listed in the Table 2).

As it was suggested before, the strategy of personnel marketing should imply a model of enterprise's actions that

Table 2. Personnel marketing strategies

\begin{tabular}{|c|c|c|c|c|c|}
\hline \multirow[b]{2}{*}{ No. } & \multicolumn{3}{|c|}{ Level of employer's attractiveness } & \multirow{2}{*}{$\begin{array}{l}\text { Personnel } \\
\text { marketing } \\
\text { strategy }\end{array}$} & \multirow[b]{2}{*}{ Description } \\
\hline & external & internal & $\begin{array}{l}\text { gene- } \\
\text { ralized }\end{array}$ & & \\
\hline 1 & low & low & low & creation & $\begin{array}{l}\text { strategy of implementation of new measures for external and internal } \\
\text { personnel marketing }\end{array}$ \\
\hline 2 & low & medium & low & creation & $\begin{array}{l}\text { strategy of implementation of new measures for external personnel mar- } \\
\text { keting and improvement of measures for internal personnel marketing }\end{array}$ \\
\hline 3 & medium & low & low & creation & $\begin{array}{l}\text { strategy of implementation of new measures for internal personnel mar- } \\
\text { keting and improvement of measures for internal personnel marketing }\end{array}$ \\
\hline 4 & low & high & medium & improvement & $\begin{array}{l}\text { strategy of implementation of new measures for external personnel } \\
\text { marketing and monitoring of existing measures for internal personnel } \\
\text { marketing }\end{array}$ \\
\hline 5 & medium & medium & medium & improvement & $\begin{array}{l}\text { strategy of improvement of existing measures both for internal and exter- } \\
\text { nal personnel marketing }\end{array}$ \\
\hline 6 & high & low & medium & improvement & $\begin{array}{l}\text { strategy of implementation of new measures for internal personnel } \\
\text { marketing and monitoring the existing measures for external personnel } \\
\text { marketing }\end{array}$ \\
\hline 7 & medium & high & high & maintenance & $\begin{array}{l}\text { strategy of monitoring internal personnel marketing measures and im- } \\
\text { provement of external personnel marketing measure }\end{array}$ \\
\hline 8 & high & medium & high & maintenance & $\begin{array}{l}\text { strategy of monitoring external personnel marketing measures and im- } \\
\text { provement of external personnel marketing }\end{array}$ \\
\hline 9 & high & high & high & maintenance & $\begin{array}{l}\text { strategy of monitoring both external and internal personnel marketing } \\
\text { measures }\end{array}$ \\
\hline
\end{tabular}


aimed at formation of the EVP on the labour market. That is why, depending on the level of external and internal employers' attractiveness, an enterprise decides which actions should be carried out in the future in order to develop its EVP on the labour market.

Tables 3 and 4 contain examples of measures that are being suggested for the implementation with an enterprise to build or to develop the external and/or internal employer's attractiveness, depending on its level. These measures are developed based on the factors forming external and internal attractiveness of the enterprise as an employer, substantiated in previous researches according to the 7Ps marketing mix from the point of view of employer.

The importance of this study results is that the developed methodology has a complex approach as to the development of personnel marketing strategy. This methodology allows selecting a most suitable and reasonable strategy by taking into consideration level of completed assessment of each

Table 3. Measures as to the increasing of the external enterprise's attractiveness as an employer

\begin{tabular}{|c|c|c|c|}
\hline \multirow{2}{*}{$\begin{array}{l}\text { Factors forming } \\
\text { external employers' } \\
\text { attractiveness }\end{array}$} & \multicolumn{3}{|c|}{$\begin{array}{l}\text { Recommended strategic and tactical measures for } \\
\text { the level of enterprise's external attractiveness as an employer }\end{array}$} \\
\hline & low & medium & high \\
\hline $\begin{array}{l}\text { P1 (Product) - } \\
\text { Position and package } \\
\text { of services according } \\
\text { to the position }\end{array}$ & $\begin{array}{l}\text { revision of the organizational } \\
\text { structure and its reorganization; use } \\
\text { services of external auditors, consul- } \\
\text { tants, experts to check and recheck } \\
\text { functional effectiveness; revision of } \\
\text { staff development programs, creation } \\
\text { and development of new ones; } \\
\text { creating programs for specialists in } \\
\text { a specific area of activity aimed at } \\
\text { increasing its attractiveness on the } \\
\text { labour market (targeted measures); } \\
\text { benchmarking on the labour market } \\
\text { aimed at identifying attractiveness } \\
\text { "levers" of successful employers from } \\
\text { the same sector }\end{array}$ & $\begin{array}{l}\text { further deployment of organizational } \\
\text { reorganization on the departmental / } \\
\text { divisional / separate business unit levels; } \\
\text { adjustment of the reorganization process } \\
\text { at the level of separate departments / di- } \\
\text { visions / business units; involvement of } \\
\text { managers of different levels of respon- } \\
\text { sibility to the reorganization process; } \\
\text { further development of career growth/ } \\
\text { development programs horizontally (for } \\
\text { personnel of separate departments / di- } \\
\text { visions / business units) or vertically (for } \\
\text { personnel of different fields of activity); } \\
\text { further development of advanced trai- } \\
\text { nings and education programs }\end{array}$ & $\begin{array}{l}\text { monitoring effectiveness of ca- } \\
\text { reer development and training } \\
\text { programs (management effecti- } \\
\text { veness analysis, feedback ana- } \\
\text { lysis, achievement of targeted } \\
\text { performance indicators) }\end{array}$ \\
\hline $\begin{array}{l}\mathrm{P} 2 \text { (Price) - } \\
\text { Compensation } \\
\text { package }\end{array}$ & $\begin{array}{l}\text { conducting audit of the rewarding } \\
\text { system, development of the a new } \\
\text { rewarding ones; benchmarking of sa- } \\
\text { laries, additional compensations and } \\
\text { bonus schemes; use services of exter- } \\
\text { nal auditors, consultants, experts to } \\
\text { review salaries competitiveness }\end{array}$ & $\begin{array}{l}\text { further implementation of new ele- } \\
\text { ments in the rewarding system; deve- } \\
\text { lopment of additional compensations, } \\
\text { financial programs, benefits }\end{array}$ & $\begin{array}{l}\text { planned revision of rewarding } \\
\text { systems, additional compensa- } \\
\text { tions; their adjustment according } \\
\text { to the trends on the external labour } \\
\text { market and in accordance with the } \\
\text { chosen HR policy }\end{array}$ \\
\hline $\begin{array}{l}\text { P3 (Place) - } \\
\text { External communi- } \\
\text { cation }\end{array}$ & $\begin{array}{l}\text { creating web-site and a centre for } \\
\text { its support and maintenance; im- } \\
\text { provement of the interactivity and } \\
\text { content of recruitment web-page; } \\
\text { involvement of external specialists } \\
\text { and consultants to develop new ap- } \\
\text { plications and improve functionality } \\
\text { of old ones }\end{array}$ & $\begin{array}{l}\text { identifying the most popular job sites, } \\
\text { placement of information there; cre- } \\
\text { ation of a special contact centre for } \\
\text { candidates (or define a contact person); } \\
\text { training and development of contact } \\
\text { centre personnel }\end{array}$ & $\begin{array}{l}\text { monitoring the effectiveness of } \\
\text { web-site management; monitoring } \\
\text { the frequency of updating infor- } \\
\text { mation; screening of the consisten- } \\
\text { cy of the information; evaluation of } \\
\text { technical support quality; routine } \\
\text { and planned check of the efficiency } \\
\text { of work and qualifications of res- } \\
\text { ponsible person; tracking the key } \\
\text { performance indicators; feedback } \\
\text { reviews }\end{array}$ \\
\hline $\begin{array}{l}\text { P4 (Promotion) - } \\
\text { External branding }\end{array}$ & $\begin{array}{l}\text { creating a page on the employer's } \\
\text { website dedicated to future employe- } \\
\text { es (accessible externally); setting up } \\
\text { an employer site attendance tracking } \\
\text { system; carrying out an advertising } \\
\text { campaign of the employer and its } \\
\text { employer value proposition through } \\
\text { different channels of communication }\end{array}$ & $\begin{array}{l}\text { development of new communication } \\
\text { channels (social networks, communi- } \\
\text { ties, clubs, etc.); introduction of new } \\
\text { communication tools to reach target } \\
\text { audiences (charity events, financial } \\
\text { support youth clubs, organizations) etc. }\end{array}$ & $\begin{array}{l}\text { monitoring employer brand reco- } \\
\text { gnition, awareness on the employ- } \\
\text { er brand values and its EVP }\end{array}$ \\
\hline $\begin{array}{l}\text { P5 (People) - } \\
\text { All categories of } \\
\text { employees contacting } \\
\text { with candidates }\end{array}$ & $\begin{array}{l}\text { development of programs to impro- } \\
\text { ve communication and negotiation } \\
\text { skills of interviewers and recruiters; } \\
\text { implementation of employee referral } \\
\text { scheme; adjustment of the dress code; } \\
\text { raising awareness about employees' } \\
\text { referral schemes }\end{array}$ & $\begin{array}{l}\text { updating the programs, changing } \\
\text { training providers, list of trainings, } \\
\text { forms of training (online, individual, } \\
\text { classroom, coaching etc.); increase of } \\
\text { employee referral bonuses; raising awa- } \\
\text { reness on the dress-code requirements }\end{array}$ & $\begin{array}{l}\text { monitoring the number of hired } \\
\text { candidates through the referral } \\
\text { schemes; collecting feedback from } \\
\text { candidates regarding the company } \\
\text { representatives with whom they } \\
\text { communicate throughout the } \\
\text { recruitment process }\end{array}$ \\
\hline
\end{tabular}


End of Table 3

\begin{tabular}{|c|c|c|c|}
\hline \multirow{2}{*}{$\begin{array}{l}\text { Factors forming } \\
\text { external employers' } \\
\text { attractiveness }\end{array}$} & \multicolumn{3}{|c|}{$\begin{array}{l}\text { Recommended strategic and tactical measures for } \\
\text { the level of enterprise's external attractiveness as an employer }\end{array}$} \\
\hline & low & medium & high \\
\hline $\begin{array}{l}\text { P6 (Process) - } \\
\text { Workflow of the } \\
\text { external personnel } \\
\text { marketing }\end{array}$ & $\begin{array}{l}\text { creating a team dedicated to admi- } \\
\text { nister process; identify and split res- } \\
\text { ponsibilities in the team, that may } \\
\text { include projects management and } \\
\text { control, control of the information } \\
\text { consistency provided to candidates; } \\
\text { management of communication } \\
\text { about the recruitment process on } \\
\text { the official website of the employer } \\
\text { for each vacancy etc. }\end{array}$ & $\begin{array}{l}\text { active use of social networks; impro- } \\
\text { vement of the process (reducing the } \\
\text { number of stages; the time spend; eli- } \\
\text { minating unnecessary elements); pro- } \\
\text { viding opportunities for employees of } \\
\text { the administrative team to take speci- } \\
\text { al advanced training courses aimed at } \\
\text { developing their skills and upgrading } \\
\text { knowledge }\end{array}$ & $\begin{array}{l}\text { analysis of candidates feedback } \\
\text { results regarding the recruitment } \\
\text { process; monitoring the skills } \\
\text { and qualifications of adminis- } \\
\text { trative team and line managers }\end{array}$ \\
\hline $\begin{array}{l}\text { P7 (Physical } \\
\text { Evidence) - } \\
\text { Physical environment } \\
\text { and conditions provi- } \\
\text { ded by the organi- } \\
\text { zation to candidates } \\
\text { during the recrui- } \\
\text { tment process }\end{array}$ & $\begin{array}{l}\text { developing expenses refund schemes } \\
\text { (e.g. expenses related with travelling } \\
\text { to the interview); changing premises } \\
\text { or repairs; creation of comfortable } \\
\text { working conditions for the emplo- } \\
\text { yees at the reception }\end{array}$ & $\begin{array}{l}\text { increasing limits for expenses refund; } \\
\text { providing additional services (the } \\
\text { Internet access, recreation rooms on- } \\
\text { site) etc. }\end{array}$ & $\begin{array}{l}\text { monitoring the refunds policies } \\
\text { compliance with the market pri- } \\
\text { ces; conducting inspection of the } \\
\text { working conditions; upgrading } \\
\text { services }\end{array}$ \\
\hline
\end{tabular}

Table 4. Measures as to the increasing of the external enterprise's attractiveness as an employer

\begin{tabular}{|c|c|c|c|}
\hline \multirow{2}{*}{$\begin{array}{l}\text { Factors forming } \\
\text { internal employ- } \\
\text { ers' attractiveness }\end{array}$} & \multicolumn{3}{|c|}{$\begin{array}{l}\text { Recommended strategic and tactical measures for } \\
\text { the level of enterprise's internal attractiveness as an employer }\end{array}$} \\
\hline & low & medium & high \\
\hline $\begin{array}{l}\text { P1 (Product) - } \\
\text { Providing services } \\
\text { according to the } \\
\text { position received }\end{array}$ & $\begin{array}{l}\text { revision of the organizational structure } \\
\text { and its reorganization; use services of } \\
\text { external auditors, consultants, experts } \\
\text { to check and recheck functional effecti- } \\
\text { veness; revision of personnel develo- } \\
\text { pment programs, creation and develo- } \\
\text { pment of new ones; creating programs } \\
\text { for specialists in a specific area of activi- } \\
\text { ty aimed at increasing its attractiveness } \\
\text { on the labour market (targeted measu- } \\
\text { res); benchmarking on the labour mar- } \\
\text { ket aimed at identifying attractiveness } \\
\text { "levers" of successful employers from } \\
\text { the same sector; creating programs to } \\
\text { promote and position the area of acti- } \\
\text { vity (jobs) within the enterprise among } \\
\text { middle or lower level managers }\end{array}$ & $\begin{array}{l}\text { further deployment of organizatio- } \\
\text { nal reorganization on the depar- } \\
\text { tmental / divisional / separate bu- } \\
\text { siness units' levels; adjustment of } \\
\text { reorganization process at the level } \\
\text { of separate departments / divisions } \\
\text { / business units; involvement of ma- } \\
\text { nagers of different levels of respon- } \\
\text { sibility to the reorganization pro- } \\
\text { cess; further development of career } \\
\text { growth/development programs ho- } \\
\text { rizontally (for personnel of separate } \\
\text { departments / divisions / business } \\
\text { units) or vertically (for personnel of } \\
\text { different fields of activity); further } \\
\text { development of advanced trainings } \\
\text { and education programs }\end{array}$ & $\begin{array}{l}\text { planned analysis or routine checks } \\
\text { of positions, their titles, grades' } \\
\text { consistency with their levels of } \\
\text { responsibilities and decision } \\
\text { making; monitoring the number } \\
\text { of employees who have changed } \\
\text { positions within the enterprise } \\
\text { (rotation, promotion, resigna- } \\
\text { tions etc.); monitoring effective- } \\
\text { ness of career development and } \\
\text { training programs (management } \\
\text { effectiveness analysis, feedback } \\
\text { analysis, achievement of targeted } \\
\text { indicators) }\end{array}$ \\
\hline $\begin{array}{l}\text { P2 (Price) - } \\
\text { Compensation } \\
\text { package }\end{array}$ & $\begin{array}{l}\text { conducting audit of the rewarding sys- } \\
\text { tem, development of the a new ones; } \\
\text { benchmarking of salaries, additional } \\
\text { compensations and bonus schemes; } \\
\text { use services of external auditors, con- } \\
\text { sultants, experts to review salaries com- } \\
\text { petitiveness }\end{array}$ & $\begin{array}{l}\text { further implementation of new } \\
\text { elements in the rewarding system; } \\
\text { development of additional compen- } \\
\text { sations, financial programs, benefits }\end{array}$ & $\begin{array}{l}\text { planned revision of rewarding } \\
\text { systems, additional compensa- } \\
\text { tions, adjustment according to } \\
\text { the trends on the external labour } \\
\text { market and in accordance with the } \\
\text { chosen policy }\end{array}$ \\
\hline $\begin{array}{l}\text { P3 (Place) } \\
\text { Internal commu- } \\
\text { nication }\end{array}$ & $\begin{array}{l}\text { creating intranet and an internal centre } \\
\text { of its support and maintenance; impro- } \\
\text { vement of the interactivity and content } \\
\text { of the internal recruitment web-page; } \\
\text { involvement of external specialists and } \\
\text { consultants to develop new applications } \\
\text { and improve functionality of old ones }\end{array}$ & $\begin{array}{l}\text { creating additional internal pages } \\
\text { of the site, special printed editions; } \\
\text { creating a special contact centre for } \\
\text { employees (or define a contact per- } \\
\text { son); training and development of } \\
\text { contact centre personnel }\end{array}$ & $\begin{array}{l}\text { monitoring the effectiveness of } \\
\text { intranet site management; mo- } \\
\text { nitoring the frequency of infor- } \\
\text { mation updating; screening the } \\
\text { relevance and consistency of the } \\
\text { information; evaluation of tech- } \\
\text { nical support quality; routine } \\
\text { and planned check of the effici- } \\
\text { ency of work and qualifications } \\
\text { of responsible persons; tracking } \\
\text { the key performance indicators; } \\
\text { feedback reviews }\end{array}$ \\
\hline
\end{tabular}


End of Table 4

\begin{tabular}{|c|c|c|c|}
\hline \multirow{2}{*}{$\begin{array}{l}\text { Factors forming } \\
\text { internal employers' } \\
\text { attractiveness }\end{array}$} & \multicolumn{3}{|c|}{$\begin{array}{l}\text { Recommended strategic and tactical measures for } \\
\text { the level of enterprise's internal attractiveness as an employer }\end{array}$} \\
\hline & low & medium & high \\
\hline $\begin{array}{l}\text { P4 (Promotion) } \\
\text { Internal branding }\end{array}$ & $\begin{array}{l}\text { creating a page on the intranet } \\
\text { dedicated to employees and HR } \\
\text { management function (accessible } \\
\text { internally); setting up the site at- } \\
\text { tendance tracking system; carrying } \\
\text { out actions and campaigns aimed at } \\
\text { promotion of the corporate cultu- } \\
\text { re, the spread and reinforcement of } \\
\text { company values etc. }\end{array}$ & $\begin{array}{l}\text { development of new communication } \\
\text { channels (creation of internal social } \\
\text { networks, communities, clubs, etc.); } \\
\text { introducing new communication } \\
\text { tools to reach target audiences (or- } \\
\text { ganizing charity events, financial } \\
\text { support of clubs of interests, sport } \\
\text { organizations, and other campaigns) }\end{array}$ & $\begin{array}{l}\text { monitoring of awareness about EVP } \\
\text { internally; evaluation of employer } \\
\text { values understanding by employees }\end{array}$ \\
\hline $\begin{array}{l}\text { P5 (People) - } \\
\text { All categories of HR } \\
\text { function and people } \\
\text { managers of all } \\
\text { functions }\end{array}$ & $\begin{array}{l}\text { development of programs to impro- } \\
\text { ve communication and negotiation } \\
\text { skills of the managers; development } \\
\text { of the open-door culture; implemen- } \\
\text { tation of the re-integration/on-boar- } \\
\text { ding programs; adjustment of the } \\
\text { dress code; raising awareness about } \\
\text { employee referral schemes }\end{array}$ & $\begin{array}{l}\text { updating of programs, changing } \\
\text { training providers, list of trainings, } \\
\text { forms of training (online, individual, } \\
\text { classroom, coaching etc.); increase } \\
\text { employee referral bonuses; raise } \\
\text { awareness on the dress-code requi- } \\
\text { rements; updating behaviour guide- } \\
\text { lines internally }\end{array}$ & $\begin{array}{l}\text { monitoring the number of hired } \\
\text { candidates through the referral } \\
\text { schemes; collecting feedback from } \\
\text { candidates regarding the managers } \\
\text { and their managerial qualities }\end{array}$ \\
\hline $\begin{array}{l}\text { P6 (Process) - } \\
\text { Workflow of the } \\
\text { internal personnel } \\
\text { marketing }\end{array}$ & $\begin{array}{l}\text { dedicate a team of specialists to } \\
\text { administer the process; identify } \\
\text { and split responsibilities in the team, } \\
\text { that may include management and } \\
\text { control of HR projects, control of in- } \\
\text { formation consistency provided to } \\
\text { employees; management of commu- } \\
\text { nication regarding the HR internal } \\
\text { process reflected on the intranet or } \\
\text { employees HR portal }\end{array}$ & $\begin{array}{l}\text { use of other modern tools (internal } \\
\text { social networks, portals, chats etc); } \\
\text { improvement of the internal person- } \\
\text { nel management processes and their } \\
\text { coordination (time savings, provi- } \\
\text { ding additional investment needed } \\
\text { for the improvement, eliminating } \\
\text { outdated processes etc.); providing } \\
\text { opportunities to employees of the } \\
\text { administrative team to take special } \\
\text { advanced training courses aimed at } \\
\text { developing their skills and upgra- } \\
\text { ding knowledge }\end{array}$ & $\begin{array}{l}\text { analysis of employees feedback } \\
\text { results regarding the processes, } \\
\text { projects, campaigns conducted by } \\
\text { the HR function; monitoring of the } \\
\text { skills and qualifications of adminis- } \\
\text { trative team and line managers }\end{array}$ \\
\hline $\begin{array}{l}\text { P7 (Physical } \\
\text { Evidence) - } \\
\text { Physical environ- } \\
\text { ment and conditions } \\
\text { provided by the } \\
\text { organization to its } \\
\text { employees during } \\
\text { their work }\end{array}$ & $\begin{array}{l}\text { developing expenses refund schemes } \\
\text { (e.g. expenses related with travelling } \\
\text { to the work); providing employees } \\
\text { with the food at work; creation of } \\
\text { comfortable working conditions for } \\
\text { employees (changing the premises } \\
\text { or carrying out repairs, ensuring } \\
\text { security on site; cleaning offices on } \\
\text { time etc.) }\end{array}$ & $\begin{array}{l}\text { adding refund of additional expen- } \\
\text { ses (e.g. for fuel, food, mobile phone } \\
\text { etc); providing additional services } \\
\text { (the Internet access, recreation } \\
\text { rooms on-site, buying additional } \\
\text { information tools and technolo- } \\
\text { gies) etc. }\end{array}$ & $\begin{array}{l}\text { monitoring the refunds policies } \\
\text { compliance with the market prices; } \\
\text { scheduling inspection of the wor- } \\
\text { king conditions; upgrading IT tools } \\
\text { and services }\end{array}$ \\
\hline
\end{tabular}

factor representing 7Ps personnel marketing mix. Each one of nine strategies predefine a set of measures that can be directly implemented in any enterprise in order to improve indicators of each factor and as a result the generalised level of employer attractiveness, ensuring long-term future and existing employee attraction, engagement and retention.

\section{Conclusions}

The aim of the research was to identify stages of the process of personnel marketing strategy development and to define the main types of possible strategies.

The main stages of the process of personnel marketing strategy development were identified. This process has an integrated approach - it is formed based on two types of personnel marketing - internal and external. Strategy of external personnel marketing is aimed at attracting potential employees by developing an external enterprise's attractiveness as an employer. Likewise strategy of internal personnel marketing is aimed at retaining existing employees by developing an internal enterprise's attractiveness as an employer.

Selection of the personnel marketing strategy is suggested to be done based on the Matrix identifying generalized level of enterprise's attractiveness as an employer. This Matrix allows defining 9 types of personnel marketing strategies by matching results of evaluation of external and internal enterprise's attractiveness level preliminarily received from potential employees on labour market and existing employees accordingly. 
The essence of each type of personnel marketing strategy was substantiated. Main measures for each type of strategy were developed aiming at the improvement of the of enterprise's attractiveness as an employer externally and internally. These measures were elaborated based on the 7Ps personnel marketing mix.

Implementation of the developed measures should enable enterprise to reduce costs as to the employee's attraction and retention, as well as to improve its personnel qualitative and quantitative indicators.

Next researches should be aimed at development of the process of the personnel marketing strategy realization within an enterprise.

\section{References}

Ambler T, Barrow S (1996) The employer brand. The Journal of Brand Management 4: 185-206. https://doi.org/10.1057/ bm. 1996.42

Arnold J (2018) Creating an optimal employee experience: How to engineer an environment geared to the needs of your most important customers. HR Magazine 63 (5): 76-81.

Backhaus K, Tikoo S (2004) Conceptualizing and researching employer branding. Career Development International 9: 501517 https://www.researchgate.net/publication/235310489_ Conceptualizing_and_researching_employer_branding

Bersin J, Mazor A, Flynn J, Melian V (2017) The employee experience: Culture, engagement, and beyond. 2017 Global Human Capital Trends. Deloitte Insights https://www2.deloitte.com/ insights/us/en/focus/human-capital-trends/2017/improvingthe-employee-experience-culture-engagement.html

Botha A, Bussin M, De Swardt L (2011) An employer brand predictive model for talent attraction and retention. SA Journal of Human Resource Management 9 (1): 1-12 https:// sajhrm.co.za/index.php/sajhrm/article/view/388

Chhabra NL, Mishra A (2008 November) Talent management and employer branding: retention battle strategies. The IUP Journal of Management Research 11: 50-61.

Collins CJ, Stevens CK (2002) The relationship between early recruitment-related activities and the application decisions of new labor-market entrants: a brand equity approach to recruitment. Journal of Applied Psychology 87 (6): 1121-1133. https://doi.org/10.1037/0021-9010.87.6.1121

Del Rowe S (2018) An empowered workforce needs a culture of engagement: Employee engagement, employee experience, and employee enablement have to come together. CRM Magazine 22 (8): 12-13.

Deloitte (2017) Consulting Company Deloitte https://www2. deloitte.com

Ellis RK (2018) Employee experience essentials, TD: Talent Development 72 (12): 23-25.

Gilani H, Cunningham L (2017) Employer branding and its influence on employee retention. The Marketing Review 17 (2): 239-256 https://www.researchgate.net/publication/320104528_Employer_branding_and_its_influence_on_ employee_retention_A_literature_review
Gladka O (2013) Otsinka pryvablyvosti pidpryiemstva yak robotodavtsia na rynku pratsi. Ekonomika transportnoho kompleksu 21: 62-72 https://cyberleninka.ru/article/n/ otsenka-privlekatelnosti-predpriyatiya-kak-rabotodatelyana-rynke-truda

Harter J (2018) Design an employee experience that attracts star talent, gallup news service. Business Source Elite, 3-3 https:// www.gallup.com/workplace/243206/\%20design-employeeexperience-attracts-star-talent.aspx

Hays (2017) International recruitment company Hays www. hays-index.com

Hulce S (2018) Focus on candidate and employee experience: How to attract and retain talent. AMA Quarterly 4 (3): 15-17.

Kotler P (1997) Marketing management. New Jersey: PrenticeHall.

Kryvoruchko O, Gladka O (2014) Otsinka vnutrishnoi pryvablyvosti pidpryiemstva yak robotodavtsia. Ekonomika transportnoho kompleksu 24: 104-116 http://nbuv.gov.ua/ UJRN/ektk_2014_24_10

Lievens F, Highhouse S (2003) The relation of instrumental and symbolic attributes to a company's attractiveness as an employer. Personnel Psychology 56: 75-102 https://onlinelibrary. wiley.com/doi/pdf/10.1111/j.1744-6570.2003.tb00144.x

Mandhanya Y, Shah M (2010) Employer branding - a tool for talent management. Global Management Review 4 (2): 43-48.

Maxwell R, Knox S (2009) Motivating employees to "live the brand": a comparative case study of employer brand attractiveness within the firm. Journal of Marketing Management 25 (9-10): 893-907. https://doi.org/10.1362/026725709X479282

Minchington B (2011 September) Employer branding without borders: A pathway for corporate success. Journal of Corporate Recruiting Leadership: 3-14 https://www.ere.net/employerbranding-without-borders-a-pathway-to-corporate-success/

Morgan J (2016) What Is employee experience? Forbes https:// www.forbes.com/sites/jacobmorgan/2016/04/22/what-isemployee-experience/\#153532567386

Morgan J (2018) The technological environment in employee experience. Leader to Leader 2018 (87): 28-35. https://doi. org/10.1002/ltl.20340

Moroko L, Uncles MD (2008 March) Characteristics of successful employer brands. Journal of Brand Management 16 (3): 160175 https://www.researchgate.net/publication/240644238_ Characteristics_of_successful_employer_brands

Oxford Economics (2017) Oxford Economics global forecasting and quantitative analysis https://www.oxfordeconomics.com

Potgieter A, Doubell M (2018) Employer branding as a strategic corporate reputation management tool. African Journal of Business and Economic Research 13 (1): 135-155. https:// doi.org/10.31920/1750-4562/2018/v13n1a5

Randstad (2017) Randstad Group https://www.randstad.com/

Robertson A, Khatibi A (2013) The influence of employer branding on productivity-related outcomes of an organization. The IUP Journal of Brand Management 3: 17-32.

Seiko A (2018) It's not a job, it's an employee experience: To recruit and retain the best workers in the ir markets, Nvidia, Ingersoll Rand and Genentech have all adopted a more 
holistic approach to employee management, Industry Week/ IW. Nov/Dec2018 267 (6): 20-23.

Sutherland MM, Torricelli DG, Karg RF (2002) Employer-of-choice branding for knowledge workers. South African Journal of Business Management 33 (4): 13.

Top Employers (2017) Top Employers Institute https://www.topemployers.com/en/
Universum (2017) Universum company https://universumglobal. com/

Wilden R, Gudergan S, Lings I (2010) Employer branding: strategic implications for staff recruitment. Journal of Marketing Management 26: 56-73 https://www.researchgate. net/publication/247494812_Employer_branding_Strategic_implications_for_staff_recruitment_Journal_of_Marketing_Management_261-2_56-73 